\title{
The contemporary state of Russian land policy
}

\author{
Mikhail Kabanenko ${ }^{1, *}$, Lyudmila Dubrova ${ }^{2}$, Natalya Andreeva $^{3}$, Lyudmila Orekhova ${ }^{2}$ and \\ Elena Ivanova $^{2}$ \\ ${ }^{1}$ The Federal agrarian scientific center of Rostov, All-Russian Research Institute of Economics and \\ Standards, 41, st. Chehova, 344006, Rostov-on-Don, Russia \\ ${ }^{2}$ Don State Technical University, 1, pl. Gagarina, 344002, Rostov-on-Don, Russia \\ ${ }^{3}$ Rostov State University of Economics (RSUE), 69, st. Bolshaya Sadovaya, 344002, Rostov-on-Don, \\ Russia
}

\begin{abstract}
The topical issues of agricultural lands efficient use and prudent management are considered in the article. The national land policy implementation mechanism, the ways of government influence on the development of land matters in Russia and on the actions of land matters participants are analyzed in the paper. Current legal and regulatory framework applied for land regulation in Russian Federation is considered. The study of Russian land policy state highlighted a number of current problems associated with inefficiency of the existing government system of land regulation and the need to improve the legislative support of agricultural land transactions. Furthermore, the issues of use and care of agricultural lands of all categories remain largely unaddressed. Within the scope of conducted study the ways of improving the national policy applicable to the land proper use are suggested.
\end{abstract}

\section{Introduction}

The land in Russia is the important component of national wealth and for this reason it is protected by the government. People used to exploit the land as the inexhaustible natural resource. However, over the years when people faced the threat of land reserves depletion, the attitude to the land changed. Since the earth is the basis of the ecosystem as a whole, its state affects the general condition of the environment. Against this background, it became necessary to study land matters and its participants: government agencies and municipalities, entities and persons.

The key factor of the land rational use is the establishment of efficient land policy, which is marked by social interactions related to the land possession and use. The land policy represents the component of the entire system of production relations. Along with the entire economic order of the society the land policy is historically developed and changed together with the changes of production forces. At all times of the history of society, the land matters are developed under the impact effect of the economic law of production relations state correspondence to the production forces level of development [1].

The land policy formation in Russia requires continuous improvement of specific components, which is impossible without participation in this process of the entire national

* Corresponding author: kabanenkomn@mail.ru 
economic science and, in particular, agricultural science [2, 3]. Russian and foreign scientists express the opinion that it is necessary to solve the immediate issues which take place in the current agro-industrial complex of the country.

Problems of land policy formation are considered in the papers of marked national and foreign scientists. A number of publications contain particular important and essential practices concerning the choice of ways to further development of the country's land policy. Highlighting the most remarkable and resonating papers, it is worth to mention the publications of such national scientists, as I.V. Varaksina, T.V. Volkova, A.S. Zharov, E.A. Kolesnik, D.A. Loginova, A.A. Turovsky, V.N. Kharkov, D.M. Khloptsov, T.B. Khudoyarov.

At the present stage of land matters development special attention should be paid to the papers of such foreign researchers, as J.D. Blauer, A.L. Gemmel, D. Kolas, T. Fabian, M. Holger, E. Jorge, S. Steiniger.

At the same time, it is necessary to continue research in this area, taking into account the alterations that occurred in land matters development over the last years.

The goal of the research is to study the land policy of Russian Federation, to reveal both favorable results and undesirable factors which took place during the development of land matters in the country, and to prove the proposals of further improvement of the country's land policy.

\section{Materials and methods}

The basic methods of land matters research include conventional methods, accepted in economics: statistical monitoring, logical analysis, comparison technique, average and relative values and time series.

The methodology of the study includes conceptual issues of economic theory in the field of agriculture, papers of national and foreign researchers and experts in this field.

At present, the regulation of land matters in Russia is carried out with the use of direct and indirect methods, where the basic tools include the land-value tax, land fair market valuation, land refund value determination, rental fee and penalties for environmental damage [4].

All methods of state influence on land use can be divided into direct and indirect methods (Figure 1).

\section{Main material}

All elements of Russian land policy are formalized and regularized in the basic laws that define the procedure of creation of land rights, its market trading and use.

The creation of land right in Russia is implemented in accordance with the Civil Code of Russian Federation, the Land Code of Russian Federation and federal acts [5].

The Land code of Russian Federation contains the best documented description of the mechanism of the country's land policy implementation, while the Constitution is the basic legal act specifying land and agricultural matters. The clauses 9 and 36 of the Constitution of Russian Federation define all forms of land ownerships: private, public (national and municipal), and others [6]. According to the Constitution of Russian Federation the listed forms of land ownership are regularized in the $17^{\text {th }}$ Chapter of the Civil Code.

Over the period 1990-2018 more than 1,500 laws and regulations (federal acts, presidential decrees, government regulations of Russian Federation and acts of other federal authorities) were issued at the federal level and more than 30,000 statutory acts were adopted at the regional level [7]. Thus far, the legal and regulatory framework is formed 
that determines the country's land policy and includes:

- the Land Code;

- the Civil Code;

- the Urban Planning Code;

- the Housing Code;

- the Tax Code;

- the Federal Act of Russian Federation of 21.12.2004 No. 172-FZ "Concerning the Transfer of Lands or Land Plots from One Category to Another";

- the Federal Act of Russian Federation of 24.07.2002 No. 101-FZ "Concerning Agricultural Land Transactions";

- the Federal Act of Russian Federation of 18.07.2005 No. 87-FZ "Concerning Land Tenure";

- the Federal Act of Russian Federation of 7.07.2003 No. 112-FZ "Concerning Personal Subsidiary Farming";

- the Federal Act of Russian Federation of 13.07.2015 No. 218-FZ "Concerning State Registration of the Real Estate";

- the Federal Act of Russian Federation of 11.06.2003 No. 74-FZ "Concerning Peasant Private Farm Holdings";

- the Federal Act of Russian Federation of 21.07.1997 No. 122-FZ "Concerning the State Registration of Rights in Immovable Property and Transactions Involving Such Property";

- the Federal Act of Russian Federation of 21.12.2001 No. 178-FZ "Concerning the Privatization of State and Municipal Property";

- the Federal Act of Russian Federation of 08.02.1998 No. 14-FZ "Concerning Limited Liability Companies";

- the Federal Act of Russian Federation of 26.12.1995 No. 208-FZ "Concerning JointStock Companies";

- the Federal Act of Russian Federation of 08.12.1995 No. 193-FZ "Concerning Agricultural Co-Operation".

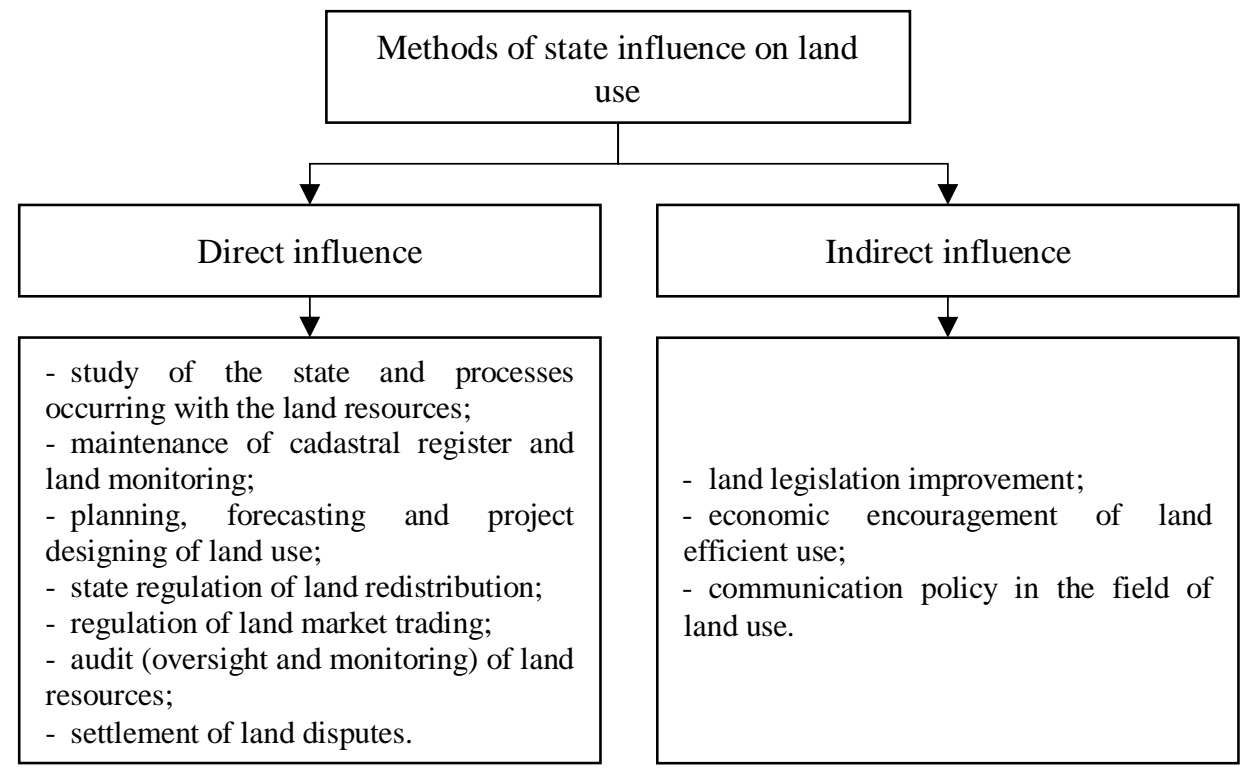

Fig. 1. The methods of the land policy implementation in Russian Federation.

The elements of land policy can be also found in the "State Program for Development 
of Agriculture and Regulation of Agricultural Commodity Markets for 2013-2020" (extended so as to expire on 2025), as well as in the subprograms "Agricultural Land Reclamation Development in Russia for 2014-2020" and "Development of National State System for Registration of Rights and Cadastral Registration of Real Estate (2014-2020)" $[8,9]$.

Over the last years, considerable support has been provided to small businesses for which the conditions for free land obtainment for farming in their own ownership or lease are established. Additionally, compensation of the part of the expenses associated with the registration of land ownership rights is also provided for small farming companies.

Quite apart from the fact that land matters are largely defined by the required legal and regulatory framework, it should be noted that some contradictions emerge in the current legal framework, many legislative acts are temporary and do not contain mechanisms for their implementation [10].

Implementation of the land policy of Russian Federation involves task sharing between the federal, regional and municipal levels of the land management system. According to the nature of land resources management, the executive authorities may be classified under general function authorities and special function authorities [11, 12].

The general function authorities regulate a wide range of land issues ignoring who is the owner or user of the land or which department handles this land use. Such authorities include the Government of Russian Federation and proper executive authorities of the regions of Russian Federation [13].

The special function authorities are subject to the general function authorities and deal with particularized issues of land matters regulation. The special function authorities are classified under functional and branch agencies (Figure 2).

\begin{tabular}{|c|c|}
\hline \multicolumn{2}{|c|}{$\begin{array}{l}\text { The Government of Russian Federation } \\
\text { (as the general function authority) }\end{array}$} \\
\hline$\nabla$ & $\nabla$ \\
\hline Functional agencies & Branch agencies \\
\hline$\nabla$ & $\nabla$ \\
\hline $\begin{array}{l}\text { - The Federal Service for State } \\
\text { Registration, Cadastre and Cartography } \\
\text { (Rosreestr); } \\
\text { - The Federal Service for Veterinary and } \\
\text { Phytosanitary } \\
\text { (Rosselkhoznadzor); } \\
\text { - The Federal Service for Supervision in } \\
\text { the Sphere of Natural Resource Use } \\
\text { (Rosprirodnadzor); } \\
\text { - The Federal Service for Environmental, } \\
\text { Industrial and Nuclear Supervision Service } \\
\text { of Russia (Rostechnadzor); } \\
\text { - The Federal Agency for State Property } \\
\text { Management (Rosimushestvo); } \\
\text { - The Federal Service for the Surveillance } \\
\text { in the Sphere of Consumer's Rights } \\
\text { Protection and Public Welfare } \\
\text { (Rospotrebnadzor). }\end{array}$ & $\begin{array}{l}\text { - The Ministry of Economic Development } \\
\text { of Russian Federation; } \\
\text { - The Ministry of Agriculture of Russian } \\
\text { Federation; } \\
\text { - The Ministry of Natural Resources and } \\
\text { Environment of Russian Federation; } \\
\text { - The Ministry of Defense of Russian } \\
\text { Federation; } \\
\text { - The Ministry of Transport of Russian } \\
\text { Federation; } \\
\text { - The Ministry of Energy of Russian } \\
\text { Federation; } \\
\text { - The Federal Security Department of } \\
\text { Russian Federation and others. }\end{array}$ \\
\hline
\end{tabular}

Fig. 2. The executive authorities implementing Russian land policy.

Each of the authorities demonstrated in Figure 2 has specific responsibilities and powers 
to implement the land policy in Russia.

The Federal Service for State Registration, Cadastre and Cartography (Rosreestr) is subject to the Ministry of Economic Development of Russian Federation and addresses the issues of state registration of land rights, performs state cadastral registration of real estate and determines the cadastral value of land.

The Federal Service for Veterinary and Phytosanitary Surveillance (Rosselkhoznadzor) reports to the Ministry of Agriculture of Russian Federation and takes charge of the environmental safety of agrochemicals use and soil fertility.

The Federal Service for Supervision in the Sphere of Natural Resource Use (Rosprirodnadzor) at the Ministry of Natural Resources and Environment of Russian Federation controls environmental management, environmental measures, state ecological appraisal and land supervision.

The Federal Service for Environmental, Industrial and Nuclear Supervision Service of Russia (Rostekhnadzor) performs environmental, technological and nuclear supervision.

The Federal Agency for State Property Management (Rosimushestvo) at the Ministry of Economic Development of Russian Federation performs management of federal property and renders services in the field of land matters.

The functions of the Federal Service for the Surveillance in the Sphere of Consumer's Rights Protection and Public Welfare (Rospotrebnadzor) include sanitation and epidemic control.

The branch executive authorities implementing the land policy in Russian Federation include ministries and agencies that are responsible for the lands of the determined purpose: the Ministry of Agriculture, the Ministry of Economic Development and the Ministry of Natural Resources and Environment.

The Ministry of Agriculture implements the functions of state policy development, state monitoring and legal regulation of agricultural land market trading.

The Ministry of Economic Development is responsible for legal regulation and development of state policy in the field of cadastral registration, cadastral valuation and land monitoring.

The Ministry of Natural Resources and Environment performs the state policy in the field of land resources study, use, reproduction and care. The Ministry is responsible for the transfer of land from one category to another, environmental protection and control.

The institutional authorities involved in land management include the Ministry of Energy, the Ministry of Defense, the Ministry of Transport, the Federal Security Department of Russia and others. The specific feature of such management is that the land plots provided have tightly earmarked purpose.

The executive authorities of the regions of Russian Federation and local government bodies establish specific authorities for implementation of the land policy and regulation of land matters [14].

Land use management bodies experienced multiple transformations over the years of reforms. Therefore the land data base is actually lost. Currently, there are no contemporary land management, planning and mapping, soil, land assessment, environmental plans, maps and materials at the regional and local level. Most localities do not have masterplans for development, borders of buffer zones [15]. A significant number of land owners do not have title establishing documents for land plots indicating corresponding regulations, rules and terms of land use. These days, the government has basically no reliable relevant land management, city-planning and environmental documentation for implementation of land policy and regulation of land matters [16].

The current structure of executive authorities implementing the land policy, both vertically and horizontally, is not related to the existing structure of country's land use, actual tasks and scope for land matters regulation by the executive authorities and local 
government bodies. The developed system discords with the statutory principles of land matters regulation and requires instant organizational change. The inefficiency of land policy implementation, major deficiencies and contraventions in the field of land use and care, irresponsibility and passivity of land authorities are explained by the imperfect structure and incompetence in the first place [17, 18].

In Russia there are no such elements of land policy implementation as land courts and banks, complete land register, centers for study of land use issues and so on. The land is not included on the state balance sheet records and enterprises balance sheet records as a resource and capital good. There are no certificates of land use provisions and environmental constraints for the land owners [19].

Thus, at present, the land use and care management is performed by various independent government bodies, it does not have any integral coordination center and is mainly focused on regulation of land matters, in which land is considered as real estate, and thereby the management does not sufficiently take into account other land functions (as natural object and natural resource).

\section{Results}

Taking in consideration the above, it may be noted that Russia remains at the initial stage of development of the national land use system, the central problems of which include the following:

- the most part of the privately owned land represents the land shares which are not indemand and are not designated in kind;

- there are no data systems for the land state monitoring;

- there is a discrepancy of the information about agricultural lands coming from regional and municipal government bodies, local agencies of Rosreestr, the Federal State Statistics Service and other references;

- the general inventory of lands is needed, which had not been conducted in Russia for many years as the Federal State Statistics Service stated summarizing the results of the first census in 2006;

- the current legal and regulatory framework is contradictory and fragmented, many legislative acts are declarative, temporary and do not contain any mechanisms for their implementation;

- there is no integral coordination center for country's land policy implementation;

- at present, the land use and care management is performed by various independent government bodies.

An additional point is that in current Russian land legislation there is a trend to prioritize issues of land registration over environmental activities. This trend leads to the disbalance of land use and care, since in this case the environmental component fades into insignificance. The priority issues should include the protection of lands of all categories.

The stake on land registration will not solve the problems of self-acquisition of demanded land not far from the city, plowing of reserves, aggravation of erosion processes and other negative developments which have been observed over the last years [20].

In this regard, regulation of the land matters, improvement of the legal and administrative mechanism for the land policy implementation is the top-priority government task, which requires accomplishment of the following measures:

- to complete inventory check conduction;

- to amend field boundaries with the financial package for citizens;

- to afford free and open access for keeping the public informed;

- to create the joint standard data base with reference to cadastral numbers;

- to provide cash indemnity to the owner as a result of mistakes occurred in the process 
of execution of documentation in the government agency;

- to state, adopt and constantly implement the well-managed land and resettlement policy;

- to develop the state land use management system which will focus country's land policy implementation within one government agency;

- to provide further development of the land ownership relations (demarcation of the state ownership of land);

- to transfer to the sure thing principle of cadastral registration;

- to establish the system of standards, regulations and rules in the field of land use.

\section{Conclusion}

The analysis of the land policy of Russian Federation shows that the issues of use and care of agricultural lands of all categories remain largely unaddressed. It can be assumed that the lack of legal framework will lead to the emergence of territories where forecasting and planning will not be implemented, that is, the development of such territories will be left unattended.

Territorial land management according to the tasks and content is the component of inter-farm land tenure, that can be defined as the system of legal, technical, social, economic and environmental measures, conducted on the specific territory for a group of farms for which the issues of inter-farm relations and planning need to be clarified and realigned [19].

It should be noted that the planning issues should be settled both at the micro and macro levels.

At the micro level there are issues concerning territorial (inter-farm) land management. These issues include creation of new and regulation of existing land matters; demarcation of localities that separate the settlement territory from agricultural land; organization of land use on resource development sites. The listed activities consist in development of investment projects of farm boundary adjustment, projects for improving agricultural land, land reclamation, land remediation, land protection from erosion, mud flows, underflood, dehydration, consolidation, pollution by the production and consumer wastes, radioactive and chemical substances and other negative effects.

At the macro level there are issues concerning land division by soil, climate, relief characteristics, reclamation degree and other indicators, forecasting issues considering the problems of future land use and redistribution solution and determination of their resource potential. The works that need to use methods of forecasting and planning at the macro level should include mapping of land management of Russian Federation territory, land management of Russian regions and municipal districts, generation of land use and protection plans.

Development of the project "Electronic atlas of agricultural lands" can serve as the basis for the plan of Russian territory land management. This project will include not only information about the area, state, degree of degradation and reclamative condition of agricultural lands, but also a number of economic indicators.

Thus, the development of current land policy should be focused on preventing negative trends in the field of land matters through constant monitoring of both national and foreign political situation, with obligatory consideration of the country's population interests. The state policy in the field of formation and building of land matters also provides background for solving internal social problems, which is necessary first of all for the rational land use and distribution. This allows maintaining the preventive function that ensures the preservation of the state territorial integrity.

The experience of land matters reform is a valuable source that can be used in future 
reforms and initiatives in contemporary Russia. It should be applied not only to solve practical tasks of the land policy, but also to continue the conceptual comprehension of social relations in contemporary Russia.

The continuous analysis of agricultural land condition is considered reasonable in line with the assessment of land matters current state and the land policy focal points planning.

\section{References}

1. Y. Griewald, Ecological Economics 151, $1-9 \quad$ (2018) doi.org/10.1016/j.ecolecon.2018.04.026

2. Y. Griewald, G. Clemens, J. Kamp, E. Gladun, N. Hölzel, H. von Dressler, Land Use Policy 68, 264-276 (2017) doi.org/10.1016/j.landusepol.2017.07.049

3. N. Stupak, Environmental Science \& Policy 68, 10-19 (2017) doi.org/10.1016/j.envsci.2016.10.003

4. V. Uzun, N. Shagaida, Z. Lerman, Land Use Policy 83, 475-487 (2019) doi.org/10.1016/j.landusepol.2019.02.018

5. A.V. Prishchepov, D. Müller, M. Dubinin, M. Baumann, V.C. Radeloff, Land Use Policy 30(1), 873-884 (2013) doi.org/10.1016/j.landusepol.2012.06.011

6. M. Bobrovsky, A. Komarov, A. Mikhailov, L. Khanina, Ecological Modelling 221(624), 953-959 (2010) doi.org/10.1016/j.ecolmodel.2009.12.013

7. A. Gugushvili, Land Use Policy 55, 142-153 (2016) doi.org/10.1016/j.landusepol.2016.03.032

8. R. Mălina Petrescu-Mag, D. Crina Petrescu, K.-O. Reti, Land Use Policy 82, 729-741 (2019) doi.org/10.1016/j.landusepol.2019.01.003

9. G. Grigoreva, M. Kabanenko, N. Andreeva, IOP Conf. Series: Earth and Environmental Science 274, 012074 (2019) doi:10.1088/1755-1315/274/1/012074

10. J.A. Aznar-Sánchez, M. Piquer-Rodríguez, J.F. Velasco-Muñoz, F. Manzano$\begin{array}{lllll}\text { Agugliaro, Land Use Policy } & 104069 & \text { 819) }\end{array}$ doi.org/10.1016/j.landusepol.2019.104069

11. G. Kust, O. Andreeva, V. Lobkovskiy, N. Telnova, Environmental Science \& Policy 89, 348-356 (2018) doi.org/10.1016/j.envsci.2018.08.010

12. G.N. Ryazanova, IFAC-PapersOnLine $\quad \mathbf{5 2 ( 2 5 ) ,} \quad 225-230 \quad$ (2019) doi.org/10.1016/j.ifacol.2019.12.477

13. S.K. Wegren, Journal of Eurasian Studies 3(2), 193-202 (2012) doi.org/10.1016/j.euras.2012.03.010

14. P.O. Skobelev, E.V. Simonova, S.V. Smirnov, D.S. Budaev, G.Yu. Voshchuk, A.L. Morokov, Procedia Computer Science 150, 154-161 (2019) doi.org/10.1016/j.procs.2019.02.029

15. A. Chernaya, M. Kabanenko, S. Ugrimova, Conf. Series: Earth and Environmental Science 274, 012073 (2019) doi:10.1088/1755-1315/274/1/012073

16. D. Medvedev, Russian Journal of Economics 1(2), 109-129 (2015) doi.org/10.1016/j.ruje.2015.11.004

17. Yu.A. Maglinets, K.V. Raevich, G.M. Tsibulskii, Procedia Engineering 201, 331-340 (2017) doi.org/10.1016/j.proeng.2017.09.639

18. M. Baude, B.C. Meyer, M. Schindewolf, Science of The Total Environment 6591, 1526-1536 (2019) doi.org/10.1016/j.scitotenv.2018.12.455 
19. A. Battalova, Procedia Economics and Finance 27, 235-239 (2015)

20. A. Kudrin, E. Gurvich, Russian Journal of Economics 1(1), 30-54 (2015) doi.org/10.1016/j.ruje.2015.05.002 